\title{
Wetterrisiken in der landwirtschaftlichen Produktion
}

- Zur Theorie und Anwendung von Wetterindexversicherungen auf landwirtschaftlichen Betrieben, im Agribusiness und in der Agrarmikrofinanzierung -

Dissertation

zur Erlangung des Doktorgrades

der Fakultät für Agrarwissenschaften

der Georg-August-Universität Göttingen

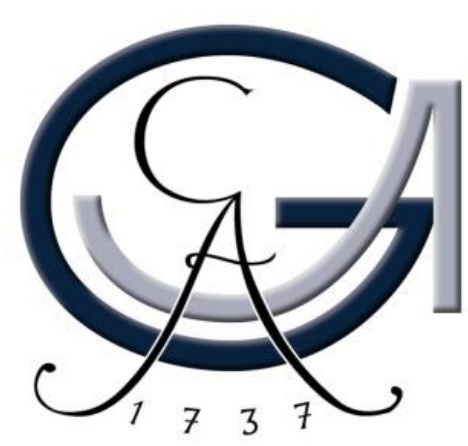

vorgelegt von

Niels Pelka

geboren in Wolfenbüttel 
1. Referent: Professor Dr. Oliver Mußhoff

2. Korreferent: Professor Dr. Stephan von Cramon-Taubadel

3. Korreferent: Professor Dr. Ludwig Theuvsen

Datum der Disputation: 04.02.2015 



\section{Danksagung}

Es ist an der Zeit mich bei denjenigen zu bedanken, die mich während der spannenden Lebensphase meiner Promotion begleitet haben.

Besonderen Dank möchte ich Herrn Professor Dr. Oliver Mußhoff aussprechen, der als Doktorvater sehr anspruchsvoll und fordernd, zugleich aber konstruktiv, zielführend und motivierend in schwierigen Phasen, sehr zum Gelingen dieser Arbeit beigetragen hat. Herrn Professor Dr. Stephan von Cramon-Taubadel und Herrn Professor Dr. Ludwig Theuvsen danke ich für die Übernahme des Zweit- und Drittgutachtens. Herrn Professor Dr. Calum Turvey danke ich für seinen wertvollen akademischen Rat und die Unterstützung meiner wissenschaftlichen Arbeit.

Mein Dank gilt weiterhin der Fachagentur Nachwachsender Rohstoffe e.V., die mir die Mitarbeit in dem Verbundprojekt „Die Zuckerrübe als Energiepflanze in Fruchtfolgen auf hoch produktiven Standorten - eine pflanzenbaulich/ökonomische Systemanalyse“ ermöglicht hat, sowie Herrn Professor Dr. Bernward Märländer und Frau Dr. Anna Jacobs, die stellvertretend für das Verbundprojekt stehen.

Ebenso geht mein Dank an meine Kollegen, die mich in den vergangenen Jahren mit bereichernden Hinweisen und Diskussionsansätzen wiederholt in neue thematische Bahnen gelenkt haben.

Nicht minder aufreibend waren die vergangenen Jahre für meine Familie, die dieses Werk in allen Phasen mit jeder möglichen Unterstützung bedacht haben. Ihnen gehört mein besonderer Dank. Insbesondere gilt dies für meine Eltern Rüdiger Pelka und Elke Glockenthör-Pelka, die mich während meiner gesamten Ausbildungszeit stets außergewöhnlich unterstützt und mental getragen haben. Danke, dass ihr Eure Liebe zu meiner Schwester Amelie und mir nie von schulischen, beruflichen oder gesellschaftlichen Leistungen abhängig gemacht und uns Raum zur Selbstfindung gegeben habt.

Darüber hinaus bin ich dankbar eine Frau wie Teresa-Marie gefunden zu haben. Teresa-Marie hat mich durch alle Höhen und Tiefen meiner Dissertation begleitet, musste so manchen meiner Fachmonologe ertragen und hat mir trotzdem stets den Rücken frei gehalten. 


\section{Inhalt}

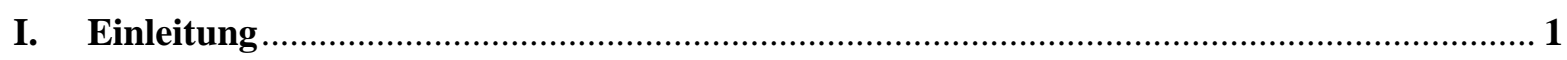

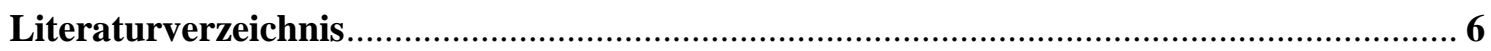

II. Hedging effectiveness of weather index-based insurance in China .................................. 10

III. Hedging effectiveness of weather derivatives in arable farming - Is there a need for mixed indices?

IV. Das Risikoreduzierungspotenzial von Wetterindexversicherungen im Agribusiness - Die Bedeutung des Aggregationsniveaus von Ertragszeitreihen

V. Does weather matter? How rainfall affects credit risk in agricultural microfinance

VI. Zusammenfassung und Schlussfolgerungen

Publikationsliste

Erklärungen über den geleisteten Eigenanteil an der Arbeit.

Eidesstattliche Erklärungen 


\section{Einleitung}

Das Wetter ist ein wesentlicher Produktionsfaktor in der Landwirtschaft und nicht vom Menschen steuerbar. Seit Anbeginn ackerbaulicher Aktivitäten sind Wetterrisiken deshalb maßgeblich für Einkommensschwankungen von Landwirten verantwortlich. Der voranschreitende Klimawandel führt dazu, dass Wetterrisiken zukünftig noch zunehmen werden (Carter et al., 2007; Morton, 2007). Hinzu kommt, dass die zunehmende Liberalisierung der Agrarmärkte die Volatilität landwirtschaftlicher Einkommen ansteigen lässt. Dies ist weltweit mit Auswirkungen für alle Akteure im Agrarsektor verbunden, vom Agrarrohstoffhandel über die praktizierenden Landwirte und den Produzenten von Betriebsmitteln bis hin zu landwirtschaftlich orientierten Banken und Versicherern.

Zur Absicherung des wirtschaftlichen Erfolges von Unternehmungen werden in den USA mit zunehmendem Erfolg Wetterindexversicherungen verwendet (Schirm, 2001; Schäfer, 2005; Norten et al., 2013). Wetterindexversicherungen, die häufig auch als Wetterderivate bezeichnet werden, haben als Instrument für das außerbetriebliche Management von Einkommensrisiken im letzten Jahrzehnt die Aufmerksamkeit der agrarökonomischen Forschung auf sich gezogen (Vedenov und Barnett, 2004; Berg et al., 2005; Lobell et al., 2007; Xu et al., 2008; Norton et al., 2013). Wetterindexversicherungen zielen auf das mengenbedingte Einkommensrisiko ab. Damit stellen sie ein Komplement zu Preisabsicherungsinstrumenten dar (Berg et al., 2005). Diese neuartige Form einer Versicherung, bei der Zahlungen in Abhängigkeit von meteorologisch objektiv messbaren Daten erfolgen, erfüllt grundsätzlich die Voraussetzungen, wetterbedingte Einkommensschwankungen zu mindern. Dabei werden wesentliche Probleme von klassischen (schadensbasierten) Versicherungsprodukten umgangen, denn Wetterindexversicherungen sind nicht von adverser Selektion und Moral-Hazard betroffen (Coble et al., 1997; Goodwin, 2001; Berg et al., 2008). Dies ist ein entscheidender Vorteil gegenüber traditionellen, d.h. schadensbasierten Versicherungsprodukten (z.B. Ertragsausfallversicherungen, Extremwetterversicherungen). Letztlich sind indexbasierte Versicherungsprodukte mit niedrigeren Transaktionskosten verbunden (Barrett et al., 2007). Bisher werden Wetterindexversicherungen überwiegend von Unternehmen der Energie- und Tourismusbranche eingesetzt (Schirm, 2001; Schäfer, 2005; Norten et al., 2013). In der Landwirtschaft ist trotz bedeutender wetterbedingter Einkommensschwankungen (Vedenov und Barnett, 2004; Berg et al., 2005; Turvey, 2005) ein verhaltener Einsatz von Indexversicherungen zu beobachten (Weather Risk Management Association, 2014). Eine entscheidende Voraussetzung für die Akzeptanz einer Versicherung ist eine Einkommensstabilisierung durch deren Anwendung. Der Grad der Einkommensstabilisierung wird auch als Risikoreduzierungspotenzial oder Hedgingeffektivität bezeichnet. Die Anwendung von Wetterindexversicherungen ist insbesondere in der Landwirtschaft mit einem Basisrisiko verbunden (Vedenov und Barnett, 2004; Berg et al., 2005; Woodard und Garcia, 2008). Dieses Basisrisiko resultiert aus einer unvollständigen Korrelation von Wetterindex und Ertrag (Turvey, 2001; Woodard und Garcia, 2008). Zum einen ergibt sich eine nicht zu versichernde Differenz des Wettergeschehens am Ort der Produktion und an der Referenzwettersta- 
tion, die als geographisches Basisrisiko bezeichnet wird (Vedenov und Barnett, 2004). Zum anderen können neben der versicherungsrelevanten Wettervariable noch weitere Einflüsse für Ertragsschwankungen verantwortlich sein (Basisrisiko der Produktion) (Norten et al., 2013). Beispielsweise können einzelbetriebliche Ertragsschwankungen auftreten, die aus regionalen Extremwetterereignissen, wie beispielsweise Hagelschlägen, resultieren.

Zur Untersuchung des Einsatzpotenzials von Wetterindexversicherungen liegt eine Reihe von Arbeiten vor. Skees (2000), Schirm (2001), Cao und Wei (2003), Schäfer (2005) sowie Heidorn und Trautmann (2005) bewerten das Einsatzpotenzial von Wetterindexversicherungen für die Absicherung von Wetterrisiken im nicht-landwirtschaftlichen Bereich. Van Asseldonk (2003) analysiert die Hedgingeffektivität von Wetterindexversicherungen im niederländischen Ackerbau. Berg et al. (2005) entwickeln eine Wetterindexversicherung mit Niederschlagsindex zur Mengenabsicherung im niedersächsischen Kartoffelanbau. Für den Winterweizenanbau quantifizieren Norten et al. (2013) das mit der Anwendung von Wetterindexversicherungen verbundene Basisrisiko am Beispiel der USamerikanischen Staaten. Gerade für Entwicklungs- und Schwellenländer sind jedoch weitere Untersuchungen notwendig, um das Risikoreduzierungspotenzial von Wetterindexversicherungen in der Landwirtschaft und die optimale Ausgestaltung dieser Versicherungen zu evaluieren. Allerdings ist es gerade für diese Länder besonders schwierig, individuelle Ertragsdaten aus der landwirtschaftlichen Produktion zu erhalten. Vor diesem Hintergrund widmet sich der erste Themenkomplex dieser Dissertation der Frage, inwieweit Wetterindexversicherungen einen Beitrag zur Einkommensstabilisierung von landwirtschaftlichen Betrieben in Entwicklungs- oder Schwellenländern leisten können (vgl. Kapitel II „Hedging effectiveness of weather index-based insurance in China“). Diese Untersuchung wird exemplarisch am Beispiel kleiner Maisproduzenten in acht Provinzen der chinesischen Hochebene durchgeführt.

Alle genannten Wirkungsanalysen im landwirtschaftlichen Bereich kommen zu dem Ergebnis, dass die Anwendung von Wetterindexversicherungen aufgrund des Basisrisikos nur zu einer vergleichsweise geringen Hedgingeffektivität führt. Die Reduzierung des Basisrisikos ist eine entscheidende Voraussetzung, um wetterbedingte Einkommensschwankungen in der Landwirtschaft mit Hilfe von Wetterindexversicherungen erfolgreich reduzieren zu können. Ein Beitrag dieser Dissertation ist es deshalb, Möglichkeiten der Reduzierung des Basisrisikos zu untersuchen. Die Literatur verfolgt hier unterschiedliche Ansätze. Beispielsweise wird diskutiert, den Rückfluss einer Wetterindexversicherung auf der Grundlage von Mischindizes zu bestimmen, die aus mehreren Wettervariablen zusammengesetzt sind. Vedenov und Barnett (2004) messen das Risikoreduzierungspotenzial von Wetterindexversicherungen mit verschiedenen Mischindizes für unterschiedliche Früchte und Regionen der USA. Xu et al. (2008) quantifizieren die Wirkung einer Wetterindexversicherung basierend auf einem Mischindex in der deutschen Getreideproduktion. Weiterhin untersucht Dischel (2001) die Absicherungsmög- 
lichkeiten durch Wetterindexversicherungen gegen negative ökonomische Konsequenzen aus bestimmten Temperatur- und Niederschlagsereignissen in der kalifornischen Mandelproduktion.

Der einer Wetterindexversicherung zugrunde liegende Index sollte einen möglichst hohen Erklärungsgehalt für den Produktionserfolg der abzusichernden Frucht liefern. Bei Mischindizes aus mehreren Wettervariablen, kann dies zu hoch komplexen Konstruktionen führen. Diese „Spezialisierung“ steht jedoch im Widerspruch zur Attraktivität der Wetterindexversicherung für potenzielle Handelspartner anderer Branchen am Markt. Mischindizes können damit die Anzahl potenzieller Handelspartner für Wetterindexversicherungen am Markt im besonderen Maße verringern. Mischindizes werden in der vorliegenden Literatur zwar gefordert und angewandt, eine vergleichende einzelbetriebliche Wirkungsanalyse von Wetterindexversicherungen mit einfachem Index und mit Mischindex für real existierende landwirtschaftliche Betriebe stellt in der Literatur jedoch eine Forschungslücke dar. Ferner unterliegen die angebotenen Wetterindexversicherungen am Markt einem mehr oder weniger starken Grad der Standardisierung. Bei einigen Anbietern ist die Wahl individueller Kumulationsperioden und des Strike-Levels möglich. Eine vergleichende einzelbetriebliche Wirkungsanalyse von Wetterindexversicherungen mit einzelbetrieblich optimal zugeschnittenem Index und standardisiertem Index ist bislang ebenfalls noch nicht durchgeführt worden. Der zweite in dieser Dissertation behandelte Themenkomplex widmet sich daher der Frage, inwiefern sich das Risikoreduzierungspotenzial einer Wetterindexversicherung, die auf einem Mischindex aus zwei Wettervariablen basiert, gegenüber dem Risikoreduzierungspotenzial einer Wetterindexversicherung, die auf einem einfachen Index aus nur einer Wettervariable basiert, unterscheidet. Weiterhin wird die Höhe und die Signifikanz des Unterschiedes zwischen der risikoreduzierenden Wirkung einer Wetterindexversicherung basierend auf einem Mischindex aus den Wettervariablen „Niederschlag“ und „Temperatur“ und der gleichzeitigen Verwendung zweier Wetterindexversicherungen mit jeweils einem einfachen Niederschlags- und Temperaturindex überprüft. Darüber hinaus wird analysiert, wie sich das Risikoreduzierungspotenzial verändert, wenn anstelle von Wetterindexversicherungen mit betriebsindividuell optimal ausgestalteten Wetterindizes nur Wetterindexversicherungen mit standardisierten Indizes verfügbar sind. Diese Frage ist besonders für Mischindizes interessant, da die Maximierung der Hedgingeffektivität hier besonders von der optimalen Ausgestaltung des Indexes abhängt und nicht zu erwarten ist, dass Anbieter von Wetterindexversicherungen für vergleichsweise kleine landwirtschaftliche Unternehmen Wetterindexversicherungen mit betriebsindividuell ausgestalteten (Misch-)Wetterindizes offerieren werden (vgl. Kapitel III „Hedging effectiveness of weather derivatives in arable farming - Is there a need for mixed indices?"). Diese Untersuchung wird exemplarisch am Beispiel von Winterweizen produzierenden Betrieben in Norddeutschland durchgeführt.

Ein weiterer Beitrag dieser Dissertation besteht darin, den Einfluss des Aggregationsniveaus von Ertragszeitreihen auf die Höhe des Basisrisikos und damit auf das Risikoreduzierungspotenzial von Wetterindexversicherungen zu untersuchen. Wetterindexversicherungen können nicht nur für land- 
wirtschaftliche Betriebe interessant sein, sondern auch für Unternehmen des Agribusiness (Meuwissen et al., 2000; Meyer, 2002; Raiffeisen, 2003). Unternehmen des Agribusiness, die ihre Rohstoffe von einer Vielzahl von Landwirten beziehen, aggregieren die Erträge dieser landwirtschaftlichen Betriebe in sich. Dies ist beispielsweise bei Biogasanlagen, Kartoffelverarbeitern, Getreidehändlern, Getreidemühlen oder Zucker verarbeitenden Unternehmen der Fall. Welche Bedeutung das Aggregationsniveau von Ertragszeitreihen für das Risikoreduzierungspotenzial von Wetterindexversicherungen hat, ist bislang allerdings noch nicht untersucht worden.

Durch das Aggregieren können Ertragsausreißer an Bedeutung verlieren, sodass sich Ertragsschwankungen der einzelnen Betriebe zu einem gewissen Maß gegenseitig ausgleichen. Dies führt zu einer Verminderung von Ertragsschwankungen auf aggregierter Ebene (Rudstrom et al., 2002; Finger, 2012), sodass die Korrelation zwischen der Ertragszeitreihe und dem Wetterindex zunehmen kann (Berg et al., 2005). Weiterhin kann es möglich sein, dass sich die nicht zu versichernde Differenz des Wettergeschehens am Ort der Produktion und an der Referenzwetterstation (geographisches Basisrisiko) verringert, da sich die unterschiedlichen Ausprägungen des Wettergeschehens auf aggregierter Ebene gegenseitig ausgleichen können. Wie zahlreiche Beispiele aus der vorliegenden Literatur zeigen, wirkt sich eine höhere Korrelation zwischen dem Wetterindex und dem Ertrag positiv auf das Risikoreduzierungspotenzial von Wetterindexversicherungen aus (Miranda, 1991; Smith et al., 1994; Turvey, 2001; Van Asseldonk, 2003; Vedenov und Barnett, 2004; Breustedt et al., 2008; Norton et al., 2013). Vor diesem Hintergrund widmet sich der dritte Themenkomplex dieser Dissertation der Frage, ob mit steigendem Aggregationsniveau von Ertragszeitreihen das Risikoreduzierungspotenzial von Wetterindexversicherungen ansteigt (vgl. Kapitel IV „Das Risikoreduzierungspotenzial von Wetterindexversicherungen im Agribusiness - Die Bedeutung des Aggregationsniveaus von Ertragszeitreihen“). Die Analyse wird exemplarisch am Beispiel eines deutschen Zucker verarbeitenden Unternehmens durchgeführt.

Aufgrund der vergleichsweise hohen Einkommensschwankungen in der landwirtschaftlichen Produktion gilt das Risiko bei der Kreditvergabe an landwirtschaftliche Betriebe im Allgemeinen und an landwirtschaftliche Klein-Betriebe in Entwicklungs- und Schwellenländern im Speziellen aus Bankensicht als besonders hoch. Gerade in diesen Ländern ist der Agrarsektor jedoch für die Ernährungssicherheit und Beschäftigung der Menschen von wesentlicher Bedeutung. Der Beitrag der Landwirtschaft zur Wertschöpfung in diesen Ländern liegt gemessen am Bruttoinlandsprodukt mit durchschnittlich $32 \%$ um das achtfache über dem weltweiten Durchschnitt (Weltbank, 2013). Rund $75 \%$ der von Armut betroffenen Menschen weltweit leben im ländlichen Raum (FAO, 2002; Weltbank, 2012), von denen wiederum betreibt die überwiegende Mehrheit Landwirtschaft. Die Förderung des privaten Unternehmertums im landwirtschaftlichen Bereich in Entwicklungs- und Schwellenländern ist daher ein wichtiger Ansatzpunkt zur Armutsbekämpfung. Dafür sind Investitionen notwendig, für die der Zugang zu Kapital unerlässlich ist. 
Seit den frühen 1990er Jahren wurden in vielen Entwicklungsländern Mikrofinanzinstitutionen (MFIs) gegründet, deren Kerngeschäft in der Bereitstellung von Finanzdienstleistungen für zumeist kleinste, kleine und mittlere Unternehmen (KKMU) besteht. Indes operieren die meisten MFIs in urbanen Gegenden und sind bisher kaum in ländlichen Regionen aktiv. Durch diesen Fokus auf urbane KKMU sind MFIs nur selten in der Lage, insbesondere die Wetterrisiken landwirtschaftlicher Unternehmen korrekt einzuschätzen (Reyes und Lensink, 2011). MFIs sind daher nur gegen hohe Risikoaufschläge und unter starker Rationierung des Kreditvolumens bereit, Kapital für landwirtschaftliche KKMUs in Entwicklungsländern zur Verfügung zu stellen (Beck et al., 2006; Diagne et al., 2000; Foltz, 2004; Petrick, 2004; Simtowe et al., 2008; Weber und Mußhoff, 2012). Für landwirtschaftliche KKMUs in Entwicklungsländern sind Investitionen, welche eine Erhöhung der Wertschöpfung nach sich ziehen und das private Unternehmertum im landwirtschaftlichen Bereich stärken könnten, mit Hilfe von Fremdkapital folglich gar nicht oder nur schwer möglich.

Risiken, die für eine MFI insbesondere mit der Vergabe von landwirtschaftlichen Krediten verbunden sind, haben in den letzten zehn Jahren die Aufmerksamkeit der agrar- und entwicklungsökonomischen Forschung auf sich gezogen (u.a. Godquin, 2004; Petrick, 2004; Beck et al., 2006; Miranda und Gonzalez-Vega, 2011; Römer et al., 2013). Einkommensrisiken in der landwirtschaftlichen Produktion, die gerade in Entwicklungs- und Schwellenländern häufig besonders hoch sind, werden immer wieder als wesentlicher Grund für das vergleichsweise schlechte Rückzahlungsverhalten von Landwirten in Entwicklungs- und Schwellenländern angeführt (Giné und Yang 2009; Miranda und GonzalezVega, 2011; Weber und Mußhoff, 2012). Einkommensrisiken gefährden die Fähigkeit landwirtschaftlicher Betriebe, z. B. ihren Kapitaldienst termingerecht bedienen zu können (Barry, 2001; Maurer, 2014), sodass es für Banken weniger attraktiv erscheint, Darlehen an Landwirte zu vergeben (Binswanger und Rosenzweig, 1986). In der Literatur wird das wetterbedingte Ertragsrisiko als wesentlicher Grund angeführt, der das Einkommen von Kleinbauern schwanken lässt und damit für das vergleichsweise hohe Kreditrisiko von landwirtschaftlichen Mikrokrediten verantwortlich ist (Christen und Pearce, 2005; IPA, 2009).

Zwar zeigen Miranda und Gonzalez-Vega (2011) anhand eines stochastischen Modells, dass Wetterereignisse in der Lage sein können, die Risikoexposition von MFIs zu erhöhen, allerdings steht die empirische Verifizierung dieser Ergebnisse noch aus. Vor diesem Hintergrund widmet sich der vierte in dieser Dissertation behandelte Themenkomplex der Frage, inwieweit Wetterrisiken das Rückzahlungsverhalten landwirtschaftlicher Mikrokreditnehmer beeinflussen (vgl. Kapitel V „Does weather matter - How rainfall affects credit risk in agricultural microfinance"). Dafür wird exemplarisch das Kreditgeschäft einer MFI in Madagaskar untersucht, die ausschließlich Mikrokredite an landwirtschaftliche und nicht-landwirtschaftliche Unternehmen vergibt. Kann ein signifikanter Einfluss von Wetterrisiken auf das Kreditrisiko nachgewiesen werden, können Wetterindexversicherungen das Potenzial haben, einen Teil des Risikos bei der Vergabe von Agrarmikrokrediten zu mindern, indem die 
Kreditvergabe mit dem Abschluss einer Wetterindexversicherung verbunden wird. Weicht der an einer Referenzwetterstation gemessene Wetterindex von einer bestimmten Zielgröße ab, kommt es zu einer Auszahlung aus der Versicherung an den Kreditgeber und dem Kreditnehmer wird die Ratenzahlung um den entsprechenden Ertrag erlassen (Carter et al., 2011; Collier et al., 2011; Shee und Turvey, 2012). Wetterindexversicherungen können daher in naher Zukunft eine wichtige Rolle im Bereich der Agrarmikrofinanzierung spielen und ein wichtiger Baustein in der Finanzsektorentwicklung werden (Barnett und Mahul, 2007).

\section{Literaturverzeichnis}

Barnett, B. und Mahul, O. (2007). Weather index insurance for agriculture and rural areas in lowerincome countries. American Journal of Agricultural Economics, Vol. 89 (5): 1241-1247.

Barrett, C.B., Barnett, B.J., Carter, M.R., Chantarat, S., Hansen, J.W., Mude, A.G., Osgood, D.E., Skees, J.R., Turvey, C.G. und Ward, M.N. (2007). Poverty Traps and Climate Risk: Limitations and Opportunities of Index-Based Risk Financing. IRI technical report, No. 2, Columbia, 2007.

Beck, T., Demirgüc-Kunt, A., Laeven, L. und Maksimovic, V. (2006). The determinants of financing obstacles. Journal of International Money and Finance, Vol. 25 (6): 932-952.

Berg, E., Schmitz, B., Starp, M. und Trenkel, H. (2005). Weather derivatives: a risk management tool in agriculture? Agrarwirtschaft, Vol. 54 (3): 158-170.

Berg, E. und Schmitz, B. (2008). Weather-based instruments in the context of whole-farm risk management. Agricultural Finance Review, Vol. 68 (1): 119-133.

Binswanger, H.P. und Rosenzweig, M.R. (1986). Behavioral and Material Determinants of Production Relations in Agriculture. Journal of Development Studies, Vol. 22 (3): 503-539.

Breustedt, G., Bokusheva, R. und Heidelbach, O. (2008). Evaluating the potential of index insurance schemes to reduce crop yield risk in an arid region. Journal of Agricultural Economics, Vol. 59 (1): $312-328$.

Cao, M. und Wei, J. (2003). Weather derivatives valuation and market price of weather risk. Working Paper. Schulich School of Business, York University, Toronto, Ontario, Canada.

Carter, T.R., Jones, R.N., Lu, X., Bhadwal, S., Conde, C., Mearns, L.O., O’Neill, B.C., Rounsevell, M.D.A. und Zurek, M.B. (2007). New assessment methods and the characterization of future conditions. Climate Change 2007: Impacts, adaptation and vulnerability. Contribution of working group II to the fourth assessment report of the intergovernmental panel on climate change. Cambridge University Press, Cambridge, UK, 133-171.

Carter, M.R., Cheng, L. und Sarrist, A. (2011). The impact of interlinked index insurance and credit contracts on financial market deepening and small farm productivity. Jahrestreffen der "American Applied Economics Association”, Pittsburgh PA, 24.-26. Juli 2011. 
Coble, K.H., Knight, T.O., Pope, R.D. und Williams, J.R. (1997). An expected-indemnity approach to the measurement of moral hazard in crop insurance. American Journal of Agricultural Economics, Vol. 79 (1): 216-226.

Collier, B., Katchova, A.L. und Skees, J.R. (2011). Loan portfolio performance and El Niño, an intervention analysis. Agricultural Finance Review, Vol. 71 (1): 98-119.

Christen, R.P. und Pearce, D. (2005): Managing risks and designing products for agricultural microfinance: Features of an emerging model. CGAP Diskussionspapier 11.

Diagne, A., Zeller, M. und Sharma, M. (2000). Empirical measurements of households' access to credit and credit constraints in developing countries: methodological issues and evidence. FCND Diskussionspapier 90. International Food Policy Research Institute, Washington.

Dischel, R.S. (2001). Double Trouble: Hedging Rainfall and Temperature. Weather Risk Report, Risk Magazine and Energy and Power Risk Management, Risk Waters Group, August: 24-26.

Finger, R. (2012). Biases in farm-level yield risk analysis due to data aggregation. German Journal of Agricultural Economics, Vol. 61 (1): 30-43.

Foltz, J.D. (2004). Credit market access and profitability in Tunisian agriculture. Agricultural Economics, Vol. 30 (3): 229-240.

Giné, X. und Yang, D. (2009). Insurance, credit, and technology adoption: Field experimental evidence from Malawi. <http://siteresources.worldbank.org/DEC/Resources/Insurance_Credit_Malawi.pdf> (Zugriff am: 21. Mai 2013).

Godquin, M. (2004). Microfinance repayment performance in Bangladesh: How to improve the allocation of loans by MFIs. World Development, Vol. 32 (11): 1.909-1.926.

Goodwin, B.K. (2001). Problems with market insurance in agriculture. American Journal of Agricultural Economics, Vol. 83 (3): 643-649.

Heidorn, T. und Trautmann, A. (2005). Niederschlagsderivate. In: HfB-Business school of Finance \& Management. Working Paper No. 69.

IPA (Innovations for Poverty Action) (2009). Improving agricultural microfinance: Barriers to the supply of agricultural lending in the Philippines. Available at: <http://www.hss.de/fileadmin/ suedostasien/philippines/downloads/090401-Improving-Agricultural-Microfinance.pdf $>$ (Zugriff am: 18. April 2014).

Lobell, D.B., Ortiz-Monasterio, J.I. und Falcon, W.P. (2007). Yield uncertainty at the field scale evaluated with multi-year satellite data. Agricultural Systems, Vol. 92 (1-3): 76-90.

Meuwissen, M.P.M., Van Asseldonk, M.A.P.M. und Huirne, R.B.M. (2000). The feasibility of a derivative for the potato processing industry in the Netherlands. Paper präsentiert beim "Meeting of 
Southern Association of Economics and Risk Management in Agriculture”. 23.-25. März 2000, Gulf Shores, Alabama.

Meyer, N. (2002). Risikomanagement von Wetterrisiken. Bibliothek Deloitte \& Touche.

Miranda, M.J. (1991). Area-yield crop insurance reconsidered. American Journal of Agricultural Economics, Vol. 73 (2): 233-242.

Miranda, M.J. und Gonzalez-Vega, C. (2011). Systemic risk, index insurance, and optimal management of agricultural loan portfolios in developing countries. American Journal of Agricultural Economics, Vol. 93 (2): 399-406.

Morton, J.F. (2007). The impact of climate change on smallholder and subsistence agriculture. Proceedings of the National Academies of Sciences 104 (2007), 19.680-19.685.

Norton, M., Osgood, D. und Turvey, C.G. (2013). Quantifying spatial basis risk for weather index insurance. The Journal of Risk Finance, Vol. 14 (1): 20-34.

Petrick, M. (2004). A microeconometric analysis of credit rationing in the Polish farm sector. European Review of Agricultural Economics, Vol. 31 (1): 77-101.

Raiffeisen (2003). Hitzewelle im August: Frankreich fehlen 16 Mio. Stück Geflügel. $<$ http://www.raiffeisen.com> (Zugriff am: 18. Januar 2014).

Reyes, A. und Lensink, R. (2011). The credit constraints of market-oriented farmers in Chile. The Journal of Development Studies, Vol. 47 (12): 1851-1868.

Römer, U., Weber, R. und Mußhoff, O. (2013). The potential of management information system data for the development of credit scoring models in microfinance. Präsentiert auf der 2. International Agricultural Risk Finance and Insurance Conference (IARFIC), Vancouver.

Rudstrom, M., Popp, M., Manning, P. und Gbur, E. (2002). Data aggregation issues for crop yield risk analysis. Canadian Journal of Agricultural Economics, Vol. 50 (2): 185-200.

Schäfer, H. (2005). Absicherung von Umsatzrisiken mit Hilfe von Wetterderivaten. Betriebswirtschaftliche Blätter, Vol. 54 (8): 463-469.

Schirm, A. (2001). Wetterderivate - Einsatzmöglichkeiten und Bewertung. Research in Capital Markets and Finance, Vol. 2001 (2): Institut für Kapitalmarktforschung und Finanzierung, LudwigMaximilians-Universität München.

Shee, A. und Turvey, C.G. (2012). Collateral-free lending with risk-contingent credit for agricultural development: indemnifying loans against pulse crop price risk in India. Agricultural Economics, Vol. 43 (5): 561-574.

Simtowe, F., Diagne, A. und Zeller, M. (2008). Who is credit constrained? Evidence from rural Malawi. Agricultural Finance Review, Vol. 68 (2): 255-272.

Skees, J.R. (2000). A role for capital markets in natural disasters: a piece of the food security puzzle. Food Policy, Vol. 25 (3): 365-378. 
Skees, J.R. und Barnett, B.J. (2006). Enhancing microfinance using index-based risk-transfer products. Agricultural Finance Review, Vol. 66 (2): 235-250.

Smith, V.H., Chouinard, H.H. und Baquet, A.E. (1994). Almost ideal area yield crop insurance contracts. Review of Agricultural Economics, Vol. 23 (1): 75-83.

Turvey, C.G. (2001). Weather derivatives for specific event risks in agriculture. Review of Agricultural Economics, Vol. 23 (2): 333-351.

Turvey, C.G. (2005). The pricing of degree-day weather options. Agricultural Finance Review, Vol. 65 (1): 59-85.

Vedenov, D.V. und Barnett, B.J. (2004). Efficiency of weather derivatives as primary crop insurance instruments. Journal of Agricultural Resource Economics, Vol. 29 (3): 387-403.

Van Asseldonk, M.A.P.M. (2003). Insurance against Weather Risk: Use of Heating Degree-days from non-local Stations for weather Derivates. Theoretical and Applied Climatology, Vol. 74 (1-2): 137144.

Weather Risk Management Association (WRMA) (2014). <http://www.wrma.org/> (Zugriff am: 31. Januar 2014).

Weber, R. und Mußhoff, O. (2012). Is agricultural microcredit really more risky? Evidence from Tanzania. Agricultural Finance Review, Vol. 72 (3): 416-435.

Woodard, J.D. und Garcia, P. (2008). Basis risk and weather hedging effectiveness. Agricultural Finance Review, Vol. 68 (1): 99-117.

Xu, W., Weber, R., Odening, M. und Mußhoff, O. (2008). Optimal design of weather bonds for reinsuring weather risk. Beitrag für das 108. EAAE Seminar "Income stabilization in a changing agricultural world: policy and tools." Warschau, Polen 2008. 


\title{
II. Hedging effectiveness of weather index-based insurance in China
}

\author{
Autoren: Niels Pelka, Oliver Mußhoff und Robert Finger \\ Veröffentlicht in: China Agricultural Economic Review, Vol. 6 (2): 212-228.
}

\begin{abstract}
Purpose - Maize production in China is exposed to pronounced yield risks, in particular weather risk, which is one of the most important and least controllable sources of risk in agriculture. The purpose of this study is to analyze the extent to which weather index-based insurance can contribute to reducing the revenue risk in maize production caused by yield variations. An average farm producing maize is analyzed for each of eight Chinese provinces, six of which are part of the Northern Plains of China.

Design/methodology/approach - Data are based on the Statistical Yearbook of China and the Chinese Meteorological Administration. The used method of insurance pricing is burn analysis. Hedging effectiveness of precipitation index-based insurance is measured by the relative reduction of the standard deviation and the Value at Risk of maize revenues.

Findings - Results reveal that precipitation index-based insurance can cause a reduction of up to $15.2 \%$ of the standard deviation and $38.7 \%$ of the Value at Risk with a $90 \%$ confidence level of maize revenues in the study area. However, there are big differences in the hedging efficiencies of precipitation index-based insurance measured at different weather stations in the various provinces. Therefore, it is recommended for insurance providers to analyze the hedging effectiveness of weather index-based insurance with regard to the geographical location of their reference weather station if they would like to offer weather index-based insurance products.
\end{abstract}

Research limitations/implications - The absence of individual, long-term yield data in the study area prevents the evaluation of risk on individual farms. Thus, the hedging effectiveness can only be analyzed on an aggregated level of yield data and can rather be modeled for an average farm of a particular province.

Originality/value - To our knowledge, this paper is the first that investigates the hedging effectiveness of precipitation index-based insurance designed for reducing revenue risk of maize production in eight Chinese provinces.

Keywords: China, weather risk, maize production, weather index-based insurance

Paper type: Research paper

JEL classification: G22, G23, Q14 


\title{
III. Hedging effectiveness of weather derivatives in arable farming - Is there a need for mixed indices?
}

\author{
Autoren: Niels Pelka und Oliver Mußhoff \\ Veröffentlicht in: Agricultural Finance Review, Vol. 73 (2): 358-372.
}

\begin{abstract}
Purpose - The use of weather derivatives is impaired with a basis risk which diminishes the hedging effectiveness and hinders the distribution of these risk management instruments in the agricultural sector. A frequently suggested approach to reduce the basis risk is the use of mixed indices composed of several weather variables. The purpose of the present study is to compare the hedging effectiveness of a simple temperature-based and a simple precipitation-based weather derivative with that of a derivative based on a mixed index of two weather variables.
\end{abstract}

Design/methodology/approach - The basis of this comparison are empirical yield time series of the winter wheat production of 32 farms located in Central Germany, as well as daily temperature and precipitation data collected by selected weather stations over several years. Insurance is structured as an option on an accumulated weather index and priced by index-value simulation. In addition, the bootstrapping method is used to improve statistical reliability. The hedging effectiveness is measured non-parametrically regarding the relative reduction of the standard deviation of winter wheat revenues caused by using weather derivatives.

Findings - The results reveal that mixed index-based weather derivatives have a significantly higher potential to reduce the risk of winter wheat revenues than simple index-based weather derivatives. However, using mixed index-based weather derivatives does not lead to a significantly higher hedging effectiveness than the simultaneous use of several simple index-based weather derivatives. Moreover, simple index-based weather derivatives may more easily raise the interest of other industries which could serve as potential trading partners for the agricultural sector.

Research limitations/implications - We analyzed the hedging effectiveness of weather derivatives based on simple and mixed indices with regard to the production of winter wheat in Central Germany. To confirm that the present results are generalizable, further research is required for other types of production apart from winter wheat cultivation and with respect to other regions besides Germany.

Practical implications - The focus and results of the present study are very relevant for farmers as well as for potential providers of weather derivatives. The results reconfirm that weather derivative providers should better offer different weather derivatives based on a simple index than complex derivatives that are based on a mixed index. 
Originality/value - To our knowledge, this paper is the first that provides a comparative impact analysis of simple and mixed index-based weather derivatives conducted for real individual farms with regard to their hedging effectiveness.

\section{Keywords:}

weather derivatives, hedging effectiveness, basis risk, simple index, mixed index 


\title{
IV. Das Risikoreduzierungspotenzial von Wetterindexversicherungen im Agribusiness - Die Bedeutung des Aggregationsniveaus von Ertrags- zeitreihen
}

\author{
Autoren: Niels Pelka und Oliver Mußhoff \\ Erscheint in: German Journal of Agricultural Economics (im Druck).
}

\section{Zusammenfassung}

Wetterindexversicherungen werden in der Landwirtschaft bisher nur verhalten eingesetzt. Als ein wesentlicher Grund hierfür werden Basisrisiken angesehen, die bei der Anwendung beim Landwirt verbleiben. Wetterindexversicherungen können allerdings auch für Unternehmen des Agribusiness interessant sein, die Erträge mehrerer landwirtschaftlicher Betriebe in sich aggregieren. Dieser Beitrag untersucht am Beispiel eines Zucker verarbeitenden Unternehmens die Bedeutung des Aggregationsniveaus von Ertragszeitreihen für das Risikoreduzierungspotenzial von Wetterindexversicherungen. Die Grundlage hierfür bilden die einzelbetrieblichen Zuckerertragszeitreihen von 40 Zuckerrüben produzierenden Betrieben sowie die aggregierte Zuckerertragszeitreihe aller rund 5.000 Zuckerrüben produzierenden Betriebe in Norddeutschland, die ihre Zuckerrüben an das betreffende Zucker verarbeitende Unternehmen liefern. Diese hoch aggregierte Zuckerertragszeitreihe beschreibt gleichzeitig das Mengenrisiko des Zucker verarbeitenden Unternehmens. Unsere Ergebnisse belegen empirisch, dass eine Hedgingeffektivität von Wetterindexversicherungen auf unterschiedlichen Aggregationsniveaus vorhanden ist und das in Folge des Aggregierens der Zuckerertragszeitreihen das Basisrisiko bei der Anwendung von Wetterindexversicherungen geschmälert und das Risikoreduzierungspotenzial gesteigert wird. Wenn das Risikoreduzierungspotenzial von Wetterindexversicherungen aus Wirksamkeitsanalysen abgeleitet wird, die mit Ertragszeitreihen einzelner landwirtschaftlicher Betriebe arbeiten, kann es für Unternehmen des Agribusiness daher unterschätzt werden. Die hier behandelte Fragestellung ist sowohl für Unternehmen des Agribusiness als auch für potenzielle Anbieter von Wetterindexversicherungen relevant.

\section{Schlüsselbegriffe}

Wetterindexversicherung, Hedgingeffektivität, Basisrisiko, Datenaggregation, Zuckerproduktion

\begin{abstract}
Weather index-based insurance is not sufficiently used in agriculture as of yet. Basis risks are considered to be a major reason for this. By the use of weather index-based insurance, basis risks remain with the farmer. However, weather index-based insurance can be interesting for agribusiness companies, specifically those which aggregate yields of several farms amongst themselves. This paper inves-
\end{abstract}


tigates the importance of the aggregation level of yield time series for the hedging effectiveness of weather index-based insurance following the example of a sugar processing company. This investigation is based on empirical sugar beet yield data from 40 sugar beet producing farms in Northern Germany. Furthermore, we work with the aggregated sugar yield time series of roughly 5,000 farms, which account for sugar beets used in the sugar processing company in question. At the same time, this highly aggregated yield time series describes the quantity risk of the sugar processing company. Our results empirically show that in consequence of aggregating the sugar yield time series, basis risk is diminished and risk reduction potential is raised through the use of weather index-based insurance. The risk reduction potential of weather index-based insurance can therefore be underestimated if it is derived from studies pertaining to yield time series at the individual farm level. The focus of the present study may be relevant for agribusiness companies, as well as for potential providers of weather derivatives.

\section{Keywords}

Weather index-based insurance, hedging effectiveness, basis risk, data aggregation, sugar production 


\title{
V. Does weather matter? How rainfall affects credit risk in agricultural microfinance
}

\author{
Autoren: Niels Pelka, Oliver Mußhoff und Ron Weber \\ Erscheint in: Agricultural Finance Review (im Druck)
}

\begin{abstract}
Purpose - Small-scale farmers in developing countries are undersupplied with capital. Although microfinance institutions have become well established in developing countries, they have not significantly extended their services to farmers. It is generally believed that this is partly due to the riskiness of lending to farmers. This paper combines original data from a Madagascan microfinance institution with weather data to estimate the effect of rainfall on the repayment performance of loans granted to farmers.
\end{abstract}

Design/methodology/approach - The basis of our empirical analysis is a unique dataset of a commercial microfinance institution in Madagascar and weather data provided by the German Meteorological Service. The repayment performance of loans granted to small-scale farmers is estimated using a twostep estimation approach based on linear probability models and a sequential logit model.

Findings - Our results reveal that an excessive amount of rain in the harvest period of rice increases the credit risk of loans granted to small-scale farmers in Madagascar. Furthermore, the results confirm that credit features affect the repayment performance of loans.

Research limitations/implications - Since the returns from weather index-based insurance (at least as a future contract) are perfectly correlated with weather events, we can set the effect of weather events on the repayment performance of loans equal to the effect of the returns of weather index-based insurance on the repayment performance of loans. Thus, our results imply that weather index-based insurance might have the potential to mitigate a certain part of the risk in agricultural lending.

Practical implications - The focus and results of the present study are very relevant for microfinance institutions, potential providers of weather index-based insurances as well as for farmers. Our results confirm that weather events are a primary reason for the risk-perception of lenders in developing countries towards small-scale farmers. Future research should, hence, concentrate on the development of index-based insurances in agricultural lending and consider interventions on different levels, e.g., insurance on the farm and the bank level.

Originality/value - To our knowledge, this is the first study that combines original loan repayment data from a Madagascan MFI with weather data in order to estimate the effect of weather events on the repayment performance of loans granted to farmers. Furthermore, to our knowledge, this is the first study that uses a two-step estimation approach based on linear probability models and a sequential logit model to investigate the repayment performance in agricultural lending. 


\section{Keywords:}

microfinance, weather risk, loan performance, sequential logit, Madagascar 


\section{Zusammenfassung und Schlussfolgerungen}

Die vorliegende Dissertation befasst sich mit der Absicherung von Wetterrisiken in der landwirtschaftlichen Produktion. Es wird die Möglichkeit der Absicherung des wirtschaftlichen Erfolges von Unternehmungen mit Hilfe von Wetterindexversicherungen untersucht. Dabei widmet sich der erste Themenkomplex dieser Dissertation der Frage, inwieweit Wetterindexversicherungen einen Beitrag zur Einkommensstabilisierung von landwirtschaftlichen Betrieben in Entwicklungs- und Schwellenländern leisten können. Die Untersuchung erfolgt auf der Grundlage von Maisertragszeitreihen unterschiedlicher Provinzen in Nordchina. Die Ergebnisse sowie weitere Wirkungsanalysen in der vorliegenden Literatur zeigen, dass die Anwendung von Wetterindexversicherungen aufgrund des mit ihrem Einsatz verbundenen Basisrisikos nur zu vergleichsweise geringen Hedgingeffektivitäten führt. Die Reduzierung des Basisrisikos ist demzufolge eine entscheidende Voraussetzung, um wetterbedingte Einkommensrisiken in der landwirtschaftlichen Produktion mit Hilfe von Wetterindexversicherungen erfolgreich mindern zu können. Der zweite und dritte Themenkomplex untersucht Möglichkeiten zur Reduzierung des mit dem Einsatz von Wetterindexversicherungen verbundenen Basisrisikos. Die Untersuchungen erfolgen auf der Grundlage einzelbetrieblicher Ertragszeitreihen aus der Winterweizenund Zuckerrübenproduktion in Norddeutschland über mehrere Jahre. Der vierte Themenkomplex dieser Dissertation untersucht, ob Wetterrisiken das Rückzahlungsverhalten landwirtschaftlicher Mikrokreditnehmer beeinflussen und inwiefern Wetterindexversicherungen in der Lage sind, die Risiken, die für eine MFI insbesondere mit der Vergabe von landwirtschaftlichen Krediten verbunden sind, zu mindern. Ziel ist es, den Zugang zu Mikrofinanzprodukten für landwirtschaftliche Betriebe zu verbessern, damit langfristig dem privaten Unternehmertum in der Landwirtschaft auch in Entwicklungsund Schwellenländern mehr Kapital für nachhaltige Investitionen zur Verfügung steht. Die Untersuchung erfolgt auf Basis von Kreditdaten der Accès Banque Madagascar für den Zeitraum 2007 bis 2012. Die Ergebnisse dieser Dissertation zielen darauf ab, eine Hilfestellung für Entscheidungsträger auf landwirtschaftlichen Betrieben, im Agribusiness und in der Agrarmikrofinanzierung bei der Anwendung von Wetterindexversicherungen zur Minderung wetterbedingter Einkommensrisiken im landwirtschaftlichen Umfeld zu sein. Darüber hinaus sollen die Ergebnisse Anbietern von Wetterindexversicherungen helfen, landwirtschaftliche Unternehmen als Kundenkreis zu erschließen.

Für die Untersuchungen zur Verringerung des Basisrisikos werden zunächst Mischindizes untersucht, die sich aus mehreren Wettervariablen zusammensetzen. Dabei wird die risikoreduzierende Wirkung einer temperaturindexbasierten und einer niederschlagsindexbasierten Wetterindexversicherung mit der einer Versicherung verglichen, das auf einem, aus beiden Wettervariablen gebildeten, Mischindex basiert. Darüber hinaus wird der Einfluss der Standardisierung von Indizes bei Wetterindexversicherungen analysiert. Die Ergebnisse belegen empirisch, dass die Verbesserung des Risikoreduzierungspotenzials durch mischindexbasierte Wetterindexversicherungen gegenüber Wetterindexversicherungen mit Einfachindizes signifikant ist. Allerdings ist die risikoreduzierende Wirkung 
einer Wetterindexversicherung basierend auf einem Mischindex nicht signifikant höher als die gleichzeitige Verwendung mehrerer Wetterindexversicherungen mit unterschiedlichen einfachen Indizes. Daher sollten diese Risikomanagementinstrumente aus folgenden Gründen nicht in Form von Mischindizes angeboten werden:

-Wetterindexversicherungen, die auf einem Mischindex basieren, der möglichst gut an die Bedürfnisse des jeweiligen landwirtschaftlichen Betriebes angepasst ist, verlieren für potenzielle Handelspartner anderer Branchen an Attraktivität.

- Die risikoreduzierende Wirkung der gleichzeitigen Verwendung mehrerer Wetterindexversicherungen mit einem einfachen Index aus nur einer Wettervariablen ist signifikant höher als die eines Mischindexes, wenn sich die Messung der Wettervariablen des Mischindexes auf dieselbe Wetterstation beschränkt.

Weiterhin zeigen die Ergebnisse, dass den Landwirten die Möglichkeit gegeben werden sollte, die Wetterindizes möglichst genau ihren betriebsindividuellen Bedingungen entsprechend zusammenstellen zu können:

- Das durchschnittliche Risikoreduzierungspotenzial von Wetterindexversicherungen sinkt mit zunehmender Standardisierung ab. Diese Reduzierung der Hedgingeffektivität ist bei allen betrachteten Indizes hoch signifikant.

- Gerade bei Mischindizes führt die Standardisierung zu einer besonders starken Reduzierung der Hedgingeffektivität von Wetterindexversicherungen.

Bei Verfügbarkeit einer zunehmenden Vielfalt von Wetterindexversicherungen mit standardisierten Indizes unterschiedlicher Kumulationsperioden besteht allerdings die Möglichkeit, sich mit einer geeigneten Mischung der Wirkung maßgeschneiderter Indizes anzunähern. Bei ausreichendem Angebot besteht das eigentliche Problem dann folglich in der Bestimmung des einzelbetrieblich optimalen Portfolios standardisierter Indizes. Somit sollte eine Vielzahl von Wetterindexversicherungen basierend auf unterschiedlichen Einfachindizes angeboten werden, die sich Landwirte individuell zusammenstellen können. Dies kann im Vergleich zu wenigen (standardisierten) Mischindizes zwar zu höheren Verwaltungskosten führen, schafft aber erst die Voraussetzung für eine breite Marktdurchdringung. Dem Landwirt muss zusätzlich eine Beratung angeboten werden, damit ihm die Wirkung von Wetterderivaten verdeutlicht werden kann und er Unterstützung bei der Bestimmung des einzelbetrieblich optimalen Indexportfolios erhält.

Der dritte Themenkomplex dieser Dissertation untersucht den Einfluss des Aggregationsniveaus von Ertragszeitreihen auf die Höhe des Risikoreduzierungspotenzials von Wetterindexversicherungen. Die Ergebnisse zeigen, dass Wetterindexversicherungen auch auf disaggregierter Ebene einen wichtigen Beitrag zur Stabilisierung des Einkommens leisten können. Allerdings kann die Risiko reduzierende Wirkung hier von Ertragszeitreihe zu Ertragszeitreihe stark schwanken. Für die von uns unter- 
suchten Zuckerertragszeitreihen steigt durch das Aggregieren der Zusammenhang zum Wetterindex. Dies mindert das Basisrisiko bei der Anwendung von Wetterindexversicherungen, sodass das Risikoreduzierungspotenzial ansteigt. In Folge des Aggregierens von Ertragszeitreihen kann das Basisrisiko bei der Anwendung von Wetterindexversicherungen geschmälert und das Risikoreduzierungspotenzial gesteigert werden. Werden Wetterindexversicherungen beispielsweise in Unternehmen des Agribusiness eingesetzt, die Ihre Rohstoffe von einer Vielzahl von Landwirten beziehen, aggregieren die Unternehmen die Erträge dieser landwirtschaftlichen Betriebe in sich. Daher kann das Risikoreduzierungspotenzial von Wetterindexversicherungen für Unternehmen des Agribusiness unterschätzt werden, wenn es aus Studien abgeleitet wird, die mit Ertragszeitreihen einzelner landwirtschaftlicher Betriebe arbeiten. Die Untersuchungen verdeutlichen, dass Wetterindexversicherungen einen wichtigen Beitrag zur Stabilisierung des landwirtschaftlichen Einkommens leisten können.

Obwohl die praktische Entwicklungshilfe in den vergangenen Jahren eine rasante Entwicklung durchschritten hat, gelten landwirtschaftliche Klein-Betriebe in Entwicklungs- und Schwellenländern als mit Kapital unterversorgt. Dies liegt daran, dass die Vergabe von Mikrokrediten an landwirtschaftliche Klein-Betriebe in Entwicklungs- und Schwellenländern aus Sicht von MFIs mit einem vergleichsweise hohen Kreditrisiko verbunden ist. Es wird häufig die Auffassung vertreten, dass landwirtschaftliche Einkommen insbesondere in Entwicklungs- und Schwellenländern hohen Schwankungen unterliegen. In der Literatur wird das wetterbedingte Ertragsrisiko als wesentlicher Grund angeführt, der das Einkommen von Kleinbauern schwanken lässt und damit für das vergleichsweise hohe Kreditrisiko von landwirtschaftlichen Mikrokrediten verantwortlich ist. Wetterbedingte Ertragsschwankungen beeinflussen die Wirtschaftlichkeit der landwirtschaftlichen Produktion und erhöhen die Volatilität des jährlichen Cash-flows. Dies gefährdet die Fähigkeit landwirtschaftlicher Betriebe, z.B. ihre Kapitaldienstverpflichtungen termingerecht bedienen zu können. Es besteht daher ein erheblicher Forschungsbedarf, inwiefern Wetterrisiken durch bestehende, sich in anderen Zusammenhängen erfolgreich bewährte Risikomanagementinstrumente abgesichert werden können, um dieses Kreditrisiko zu mindern und den Kapitalzugang für den ruralen Raum in Entwicklungsländern zu verbessern.

Wetterindexversicherungen rufen sowohl in der (agrar-) ökonomischen Literatur als auch in der Entwicklungszusammenarbeit ein wachsendes Interesse zur Absicherung dieser Risiken hervor. Daher untersucht der vierte Themenkomplex dieser Dissertation den Einfluss von Wetterrisiken auf das Rückzahlungsverhalten landwirtschaftlicher Mikrokreditnehmer. Diese Analyse erfolgt anhand der ökonometrischen Auswertung eines Datensatzes einer kommerziellen Mikrofinanzinstitution in Madagaskar. Die Analyse zeigt, dass hohe Niederschläge während der Ernteperiode das Kreditrisiko in der Untersuchungsregion signifikant erhöhen. Folglich können Wetterindexversicherungen in der Lage sein, das mit der Kreditvergabe an landwirtschaftliche Kleinbetriebe verbundenen Risiko für Mikrofinanzinstitutionen zu mindern, indem die Kreditvergabe mit dem Abschluss einer Wetterindexversicherung verbunden wird. 
Die Ergebnisse dieser Dissertation zeigen, dass die eingangs diskutierten Basisrisiken, die als ein Haupthindernis für die Etablierung von indexbasierten Wetterversicherungen im landwirtschaftlichen Umfeld gesehen werden, gemindert werden können. Zum einen ist es möglich, den Erklärungsgehalt des Wetters am abzusichernden wirtschaftlichen Erfolg einer Unternehmung durch die gleichzeitige Verwendung mehrerer Wetterindizes zu verbessern um das Basisrisiko der Produktion zu mindern. Zum anderen zeigt die vorliegende Dissertation, dass die mit der Anwendung von Wetterindexversicherungen verbundenen Basisrisiken auf aggregierter Ebene weniger von Bedeutung sind. Folglich scheinen Wetterindexversicherungen z.B. auch in Form einer Portfolioabsicherung auf Bankenebene gut für das Risikomanagement von MFIs geeignet zu sein. Weicht der an einer Referenzwetterstation gemessene Wetterindex von einer bestimmten Zielgröße ab, kommt es zu einer Auszahlung aus der Versicherung an den Kreditgeber und dem Kreditnehmer wird die Ratenzahlung um den entsprechenden Ertrag erlassen. Ein entsprechendes Risikoreduzierungspotenzial der Wetterindexversicherungen vorausgesetzt, könnten Risikoaufschläge bei der Kreditvergabe gemindert und der Kapitalzugang für den ruralen Raum in Entwicklungsländern verbessert werden.

Die vorliegenden Analysen zeigen, dass Risikomanagementinstrumente im Allgemeinen und Wetterindexversicherungen im Speziellen grundsätzlich das Potenzial haben, in naher Zukunft eine wichtige Rolle im Bereich der Agrarmikrofinanzierung spielen und ein wichtiger Baustein in der Finanzsektorentwicklung zu werden. In den Untersuchungen dieser Dissertation wurde allerdings lediglich der Zusammenhang zwischen Kreditrisiken und Wetterrisiken untersucht. Insbesondere die Höhe des Potenzials von Wetterindexversicherungen als Instrument der Rückversicherung von Wetterrisiken für MFIs blieb jedoch unberücksichtigt. Darüber hinaus sollten nachfolgende Forschungsarbeiten auch den Zusammenhang von Produktpreisrisiken und Kreditrisiken untersuchen. Neben der Identifikation und Quantifizierung dieser Effekte besteht weiterer Forschungsbedarf, inwiefern Produktpreisrisiken in der Agrarmikrofinanzierung durch bestehende, sich in anderen Zusammenhängen erfolgreich bewährte Risikomanagementinstrumente (z.B. über die Warenterminbörse) abgesichert werden können.

Insgesamt sind die in dieser Dissertation dargelegten Ergebnisse nicht zu verallgemeinern. Weiterer Forschungsbedarf besteht für die Wirkung von Wetterindexversicherungen in anderen Produktionsrichtungen und in anderen Regionen. Weiterhin sollte das Risikoreduzierungspotenzial von Wetterindexversicherungen im gesamtbetrieblichen Kontext (z.B. mit Blick auf die Streuung des Gesamtdeckungsbeitrages) und nicht allein für eine Produktionsrichtung quantifiziert werden. Die Untersuchung des Risikoreduzierungspotenzials von drei und mehr Wettervariablen in einem Index bietet ebenfalls Forschungsbedarf für weiterführende Studien. Aufgrund der Neuartigkeit von Wetterindexversicherungen erscheint außerdem die Frage der Akzeptanz von Landwirten und agrarwirtschaftlichen Unternehmen für Wetterindexversicherungen relevant, die man unter anderem über Befragungen erfassen könnte. 


\section{Publikationsliste}

\section{Beiträge veröffentlicht in referierten wissenschaftlichen Zeitschriften:}

Pelka, N. und Mußhoff, O. (2013). Hedging effectiveness of weather derivatives in arable farming Is there a need for mixed indices? Agricultural Finance Review, Vol. 73 (2): 358-372.

Pelka, N. und Mußhoff, O. (2013). Das Risikoreduzierungspotenzial von Wetterderivaten im Ackerbau: Einfachindizes versus Mischindizes. German Journal of Agricultural Economics, Vol. 62 (4): 231-243.

Jacobs, A., Auburger, S., Bahrs, E., Brauer-Siebrecht, W., Buchholz, M., Christensen, O., Götze, P., Koch, H.-J., Mußhoff, O., Pelka, N., Rücknagel, J. und Märländer, B. (2013). Die Zuckerrübe als Energiepflanze in Fruchtfolgen auf hoch produktiven Standorten - eine pflanzenbaulich/ökonomische Systemanalyse. Sugar Industry, Vol. 138 (9): 49-59.

Pelka, N., Mußhoff, O. und Finger, R. (2014). Hedging effectiveness of weather index-based insurance in China. China Agricultural Economic Review, Vol. 6 (2): 212-228.

Pelka, N. und Mußhoff, O. (2015). Das Risikoreduzierungspotenzial von Wetterindex versicherungen im Agribusiness - Die Bedeutung des Aggregationsniveaus von Ertragszeitreihen. German Journal of Agricultural Economics (im Druck).

Pelka, N., Mußhoff, O. und Weber, R. (2015). Does weather matter? How rainfall affects credit risk in agricultural microfinance. Agricultural Finance Review (im Druck).

Pelka, N., Buchholz, M. und Mußhoff, O. (2015). Die gesamtbetriebliche Bewertung von Zuckerrüben mit dem Produktionsziel Biogas unter Berücksichtigung von Risiko. Berichte über Landwirtschaft, Vol. 93 (1) (im Druck).

\section{Tagungsbeiträge:}

Pelka, N. und Mußhoff, O. (2012). Hedging Effectiveness of Weather Derivatives in Arable Farming - Is there a Need for Mixed Indices? International Agricultural Risk, Finance and Insurance Conference (IARFIC), June 20-21, 2012, in Beijing, China.

Pelka, N. und Mußhoff, O. (2013). The Potential of index-based weather insurance to mitigate credit risk in agricultural microfinance. International Agricultural Risk, Finance and Insurance Conference (IARFIC), June 16-18, 2013, Vancouver, BC, Canada.

Pelka, N. und Mußhoff, O. (2013). Das Potenzial von Wetterindexversicherungen zur Reduzierung des Ausfallrisikos von Mikrokrediten. Tagungsband der 41. Jahrestagung der Schweizer Gesellschaft für Agrarwirtschaft und Agrarsoziologie und der 23. Jahrestagung der Österreichischen Gesellschaft für Agrarökonomie: 85-86.

Jacobs, A., Brauer-Siebrecht, W., Götze, P., Pelka, N. und Auburger, S. (2013). Die Zuckerrübe als Energiepflanze in Fruchtfolgen auf hoch produktiven Standorten - eine pflanzenbaulich/ökonomische Systemanalyse. 11. Göttinger Zuckerrübentagung, 5. September 2013 in Göttingen, Deutschland. 


\section{Erklärungen über den geleisteten Eigenanteil an der Arbeit}

Hiermit erkläre ich den geleisteten Anteil an den in die Dissertationsschrift aufgenommenen Veröffentlichungen.

Im ersten Beitrag mit dem Titel „Hedging effectiveness of weather index-based insurance in China", der in Zusammenarbeit mit Herrn Professor Dr. Oliver Mußhoff und Herrn Professor Dr. Robert Finger verfasst wurde, sind folgende Bereiche von mir übernommen worden: Idee und Konzeption des Projektes mit Beratung durch Oliver Mußhoff, Durchführung der Rechnungen, Analyse und Interpretation der Ergebnisse jeweils in enger Zusammenarbeit mit den beteiligten Autoren.

Im zweiten Beitrag mit dem Titel „Hedging effectiveness of weather derivatives in arable farming - Is there a need for mixed indices?”, der in Zusammenarbeit mit Herrn Professor Dr. Oliver Mußhoff verfasst wurde, sind folgende Bereiche von mir übernommen worden: Idee und Konzeption des Projektes mit Beratung durch Oliver Mußhoff, Erhebung der Daten, Durchführung der Rechnungen und der Analysen sowie der Interpretation der Ergebnisse in enger Zusammenarbeit mit Oliver Mußhoff.

Im dritten Beitrag mit dem Titel „Das Risikoreduzierungspotenzial von Wetterindexversicherungen im Agribusiness - Die Bedeutung des Aggregationsniveaus von Ertragszeitreihen", der in Zusammenarbeit mit Herrn Professor Dr. Oliver Mußhoff verfasst wurde, sind folgende Bereiche von mir übernommen worden: Konzeptionelle Entwicklung des Forschungsprojektes, Erhebung der Daten, Durchführung der Rechnungen und der Analysen sowie der Interpretation der Ergebnisse jeweils in enger Zusammenarbeit mit Oliver Mußhoff.

Im vierten Beitrag mit dem Titel „Does weather matter? How rainfall affects credit risk in agricultural microfinance", der in Zusammenarbeit mit Herrn Professor Dr. Oliver Mußhoff und Dr. Ron Weber verfasst wurde, sind folgende Bereiche von mir übernommen worden: Konzeptionelle Entwicklung des Forschungsprojektes, Durchführung der Rechnungen und der Analysen sowie der Interpretation der Ergebnisse jeweils in enger Zusammenarbeit mit den beteiligten Autoren. 


\section{Eidesstattliche Erklärungen}

Hiermit erkläre ich eidesstattlich, dass:

(1) diese Arbeit weder in gleicher noch in ähnlicher Form bereits anderen Prüfungsbehörden vorgelegen hat.

(2) ich mich an keiner anderen Hochschule um einen Doktorgrad beworben habe.

Göttingen, den

(Unterschrift)

Hiermit erkläre ich eidesstattlich, dass diese Dissertation selbstständig und ohne unerlaubte Hilfe angefertigt wurde.

Göttingen, den

(Unterschrift) 